
\title{
Effects of Phosphatic Biofertilizer with Inorganic and Organic Sources of Phosphorus on Growth and Yield of Lentil
}

\author{
M. A. Haque and M. K. Khan
}

Soil Microbiology Lab, Soil Science Division, Bangladesh Institute of Nuclear Agriculture, Mymensingh

\begin{abstract}
Field experiments were conducted to evaluate the effects of phosphatic biofertilizer with inorganic or organic sources of $\mathrm{P}$ on lentil (Lens culinaris Medikus) (var. Binamasur 2), Phosphatic biofertilizer (PB). All the fertilizers and cowdung were applied on the basis of soil test values and Integrated Plant Nutrient System (IPNS). Mixed cultures of two phosphate solubilizing bacteria were used as phosphatic biofertilizer (PB). PB was applied as liquid form with lentil seeds before sowing. Phosphatic biofertilizer with inorganic or organic sources of $\mathrm{P}$ influenced the growth and yield attributes and yields of lentil at both the locations. Phosphatic biofertilizer with $50 \%$ P from TSP gave the highest seed and stover yields as well as total P uptake by lentil compared to the $100 \% \mathrm{P}$ from TSP. The results revealed that $50 \%$ inorganic or organic sources of $\mathrm{P}$ can be saved by the integrated using of phosphatic biofertilizer for the lentil cultivation in Bangladesh.
\end{abstract}

Keywords: Manures, Lentil yield, Phosphatic biofertilizer, P fertilizer, P uptake

\section{Introduction}

Phosphorus is one of the major plant nutrients which is essential for the growth of normal plants. As a component of every living cell, phosphorus controls all living processes including heredity and energy transport system (Donahue et al., 1990). Most agricultural soils contain larger amount of fixed form of $\mathrm{P}$ than available $\mathrm{P}$, a considerable part of which has accumulated as a consequence of regular applications of $\mathrm{P}$ fertilizers. However, a large proportion of soluble inorganic phosphate added to soil is rapidly fixed as insoluble forms soon after application and becomes unavailable to the plants. In acid soils, free oxides and hydroxides of $\mathrm{Al}$ and $\mathrm{Fe}$ fix $\mathrm{P}$, while in alkaline soils it is fixed by $\mathrm{Ca}$ (Vassileva et al., 2001; Khiari and Parent, 2005). Hence P availability in the soil to the crops is very low. Certain microorganisms such as phosphate solubilizing bacteria (Psudomonas sp., Bacillus sp., Micrcoccus sp. etc), fungi (Aspergillus sp. Pencillium sp. etc.), actinomycetes mostly those associated with the plant rhizosphere are known to convert insoluble inorganic phosphorus into soluble form that could be utilized by the plants (Vikram, 2007; Fankem et al., 2006). Among them, some phosphate-solubilizing bacteria (PSB) are being used as phosphatic biofertilizers for crop production (Rudresh et al., 2005; Alam et al., 2002). They occur in soil but usually their numbers are not high enough to rhizosphere of plants. Therefore, for agronomic utility, inoculation of plants or seeds by PSB at a much higher concentration than those normally found in soil is necessary to take advantage of their beneficial properties for plant yield enhancement (Chang and Yang, 2009).
Lentil is the most important pulse crop in Bangladesh to meet up the protein shortage for ever rising population. Phosphorus $(\mathrm{P})$ has much effectiveness on the growth and yield of lentil. But its yields are low due to high fixation/adsorption of applied or native $\mathrm{P}$. For this reasons, $\mathrm{P}$ fertilizer are needed to apply in higher amount to get optimum yields of lentil. Phosphate solubilizing bacteria can solubilize fixed form of $\mathrm{P}$ to available form by the secretion of various kinds of organic acids, phosphatase enzyme, growth hormones etc. and increase availability of $\mathrm{P}$ to the plants (Yadav et al., 2011; Kundu et al., 2006). In this point of view, phosphatic biofertilizer may be used as an alternate option of chemical P fertilizer for lentil cultivation. Therefore, the present study was under taken to evaluate the effects of phosphatic biofertilizer on the growth and yield of lentil at the different locations of Bangladesh.

\section{Materials and Methods}

Field experiments were conducted to evaluate the phosphatic biofertilizer with inorganic or organic sources of $\mathrm{P}$ on lentil at BINA substation, Ishurdi and BINA substation, Magura during rabi season of 2011-12. The experiments were laid out in a Randomized Complete Block Design using eight treatments with three replications. The treatments were as follows: $\mathrm{T}_{1}$ : Control, $\mathrm{T}_{2}: 100 \% \mathrm{P}$ from TSP, $\mathrm{T}_{3}: 50 \% \mathrm{P}$ from TSP, $\mathrm{T}_{4}: 100 \% \mathrm{P}$ from TSP + Phosphatic biofertilizer (PB), $\mathrm{T}_{5}: 50 \% \mathrm{P}$ from TSP + $\mathrm{PB}, \mathrm{T}_{6}: 50 \% \mathrm{P}$ from cowdung (CD), $\mathrm{T}_{7}: 50 \% \mathrm{P}$ from $\mathrm{CD}+\mathrm{PB}$ and $\mathrm{T}_{8}$ : Phosphatic biofertilizer (PB). Lentil (var. Binamasur 2) was shown on 17 and 18 November 2011 at Ishurdi and Magura, respectively. Lentil crop was harvested on 14 March 2012 at Ishurdi and 6 March 2012 at Magura.when attained at 
full maturity. Characteristics of initial soils for both the locations have been given in Table 1 . The fertilizer rates were used on the basis of soil tests (Table 2). In case of cowdung treatments, Integrated Plant Nutrient System (IPNS) was followed. Phosphatic biofertilizer (PB) was prepared with mix cultures of Pseudomonas aeruginosa and $P$. fluorescens. PB was applied as liquid form $\left(10^{9} \mathrm{cfu}\right.$ $\mathrm{ml}^{-1}$ broth) with the seeds of lentil. Soil and plant samples were chemically analyzed following standard methods. Different growth and yield attributes and yields data such as plant height $(\mathrm{cm})$, nodules number plant ${ }^{-1}$, nodule weight plant $^{-1}$, pods number plant $^{-1}$, seeds number plant ${ }^{-1}, 1000$-seed weight $(\mathrm{g})$, seed and sotver yields ha ${ }^{-1}$ were recorded. Phosphorus contents in the digested seed and stover samples were determined colorimetrically by vanadomolybdo yellow colour method (Yoshida, 1976) to estimate the total uptake of $\mathrm{P}$ by lentil crop.

Table 1. Physical, chemical and microbiological characteristics of initial soils of experimental fields at Ishurdi and Magura

\begin{tabular}{|l|c|c|}
\hline Characteristics & Ishurdi & Magura \\
\hline Textural class & Loam & Clay Loam \\
Cation exchange capacity $\left(\mathrm{cmol} \mathrm{kg}^{-1}\right)$ & 13.6 & 12.4 \\
Soil pH & 7.7 & 7.6 \\
Organic carbon (\%) & 0.60 & 0.65 \\
Total N (\%) & 0.052 & 0.064 \\
Available P $\left(\mathrm{mg} \mathrm{kg}^{-1}\right)$ & 13.33 & 14.2 \\
Total P $\left(\mathrm{mg} \mathrm{kg}^{-1}\right)$ & 1454.5 & 1420.8 \\
Exchangeable K $\left(\mathrm{cmol} \mathrm{kg}^{-1}\right)$ & 0.237 & 0.228 \\
Available S $\left(\mathrm{mg} \mathrm{kg}^{-1}\right)$ & 10.8 & 11.0 \\
PSB population $\left(\mathrm{cfu} \mathrm{g}^{-1} \mathrm{dry} \mathrm{soil)}^{-1}\right.$ & $1.2 \times 10^{4}$ & $1.4 \times 10^{4}$ \\
\hline
\end{tabular}

Table 2. Full rates $(100 \%)$ of nutrients $\left(\mathrm{kg} \mathrm{ha}^{-1}\right)$ and $50 \% \mathrm{P}$ equivalent cowdung $\left(\mathrm{t} \mathrm{ha}^{-1}\right)$ for lentil crop at Ishurdi and Magura on the basis of soil test values

\begin{tabular}{|l|c|c|c|c|}
\hline \multirow{2}{*}{ Locations } & \multicolumn{4}{|c|}{ Nutrients and cowdung rate for lentil } \\
\cline { 2 - 5 } & $\mathrm{N}$ & $\mathrm{P}$ & $\mathrm{K}$ & Cowdung \\
\hline BINA-sub station, Ishurdi & 19.0 & 23.0 & 17.1 & 0.58 \\
BINA-sub station, Magura & 19.0 & 22.0 & 18.0 & 0.55 \\
\hline
\end{tabular}

\section{Results and Discussion}

\section{Effects on growth and yield attributes}

Different growth parameters and yield attributes of lentil such as plant height $(\mathrm{cm})$, nodules plant ${ }^{-1}$ (no.), nodule weight plant $^{-1}(\mathrm{mg})$, pods plant ${ }^{-1}$ (no.), seeds plant $^{-1}$ (no.), 1000-seed weight (g) were influenced by the integrated use of phosphatic biofertilizer (PB) with inorganic or organic sources of $\mathrm{P}$ fertilizer (Figs. 1-6) at Ishurdi and Magura. The treatment $\mathrm{T}_{5}(50 \% \mathrm{P}$ from TSP + PB) gave maximum values in most of the recorded growth and yield attributes of lentil except plant height followed by the treatment $\mathrm{T}_{4}(100 \% \mathrm{P}$ from TSP $+\mathrm{PB}$ ) at both the locations. In case of plant height (Fig. 1), the treatment $\mathrm{T}_{6}(50 \% \mathrm{P}$ from CD) showed the highest values followed by the treatments $\mathrm{T}_{5}, \mathrm{~T}_{4}$, and $\mathrm{T}_{2}(100 \% \mathrm{P}$ from TSP). This might be happened due to addition of cowdung (CD) which enhanced the vegetative growth of lentil in both the locations. The treatment $\mathrm{T}_{1}$ (control) gave the lowest values in all the recorded growth and yield attributes of lentil. The results indicated that inoculation of lentil seeds by PB enhanced the growth and nodulation of lentil crops than uninoculated treatments at both the locations. Phosphorus has effectiveness on nodulation of legumes like lentil crop (Singh et al., 2000; Kumari et al., 2009). In this experiment, rhizobial biofertilizer was not used 
whereas greater numbers and weight of nodules were observed in phosphatic biofertilizer (PB) inoculated treatments than uninoculated treatments. This can be explained that PB inoculation enhanced the solubilization of phosphates in rhizosphere soil of

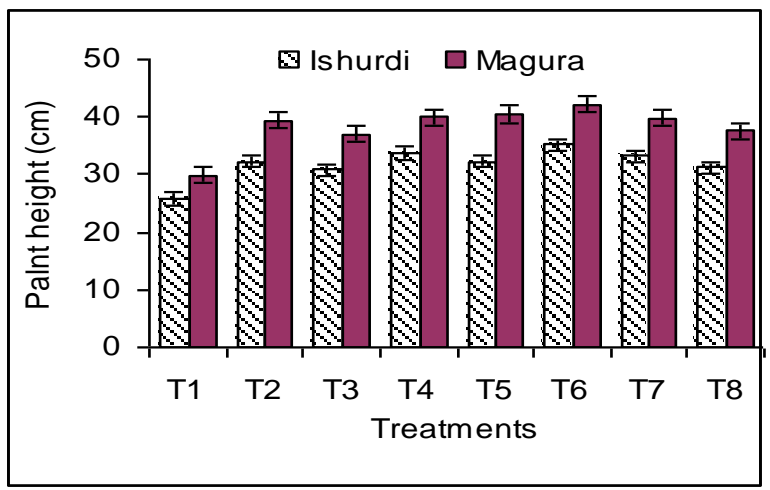

Fig.1. Effects of phosphatic biofertilizer with inorganic and organic sources of $\mathrm{P}$ on plant height of lentil

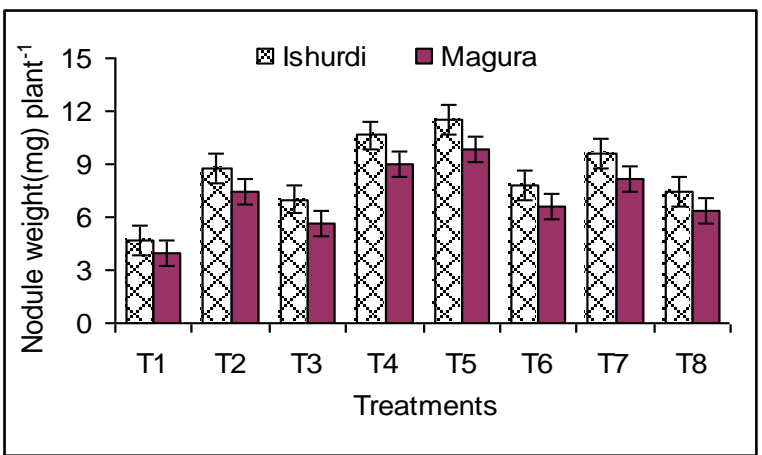

Fig.3. Effects of phosphatic biofertilizer with inorganic and organic sources of $\mathrm{P}$ on nodule weight plant $^{-1}$

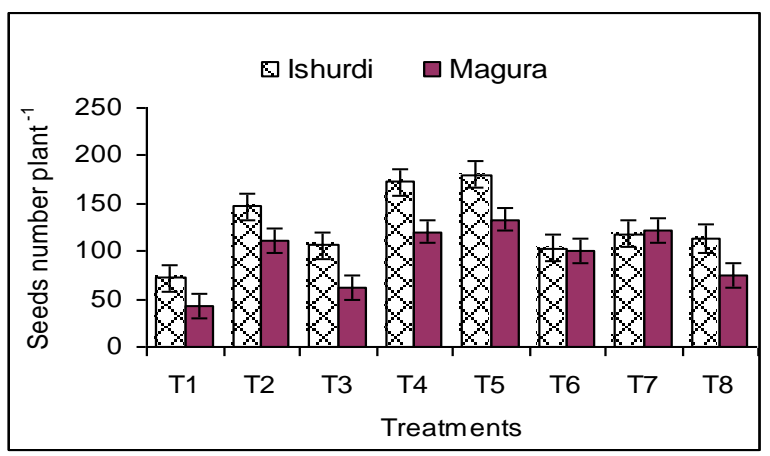

Fig.5. Effects of phosphatic biofertilizer with inorganic and organic sources of $\mathrm{P}$ on seeds plant ${ }^{-1}$ of lentil lentil which stimulated the native Rhizobium and attributed to increase the nodule number and weight (Singh et al., 2003) ultimately that showed positive effects on other growth and yield attributes of lentil (Gulletal,.2004).

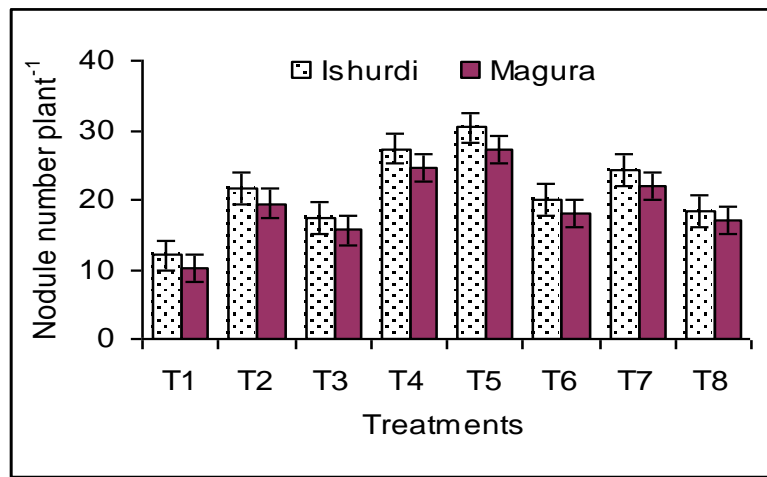

Fig.2. Effects of phosphatic biofertilizer with inorganic and organic sources of $\mathrm{P}$ on nodule number plant $^{-1}$ of lentil

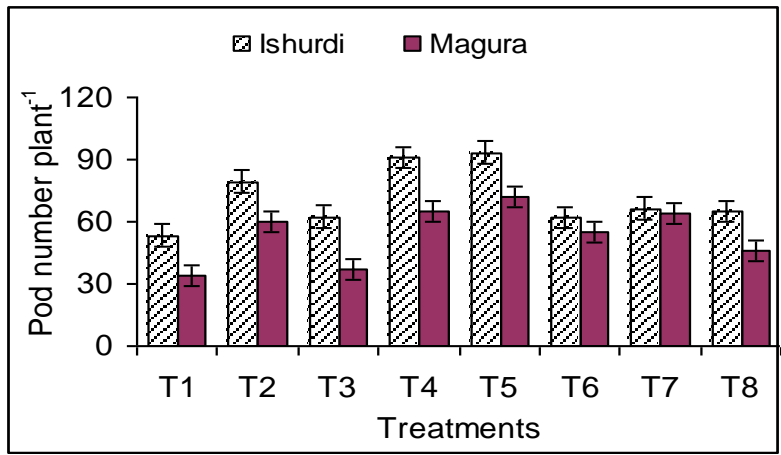

Fig. 4. Effects of phosphatic biofertilizer with inorganic and organic sources of $\mathrm{P}$ on pods plant ${ }^{-1}$

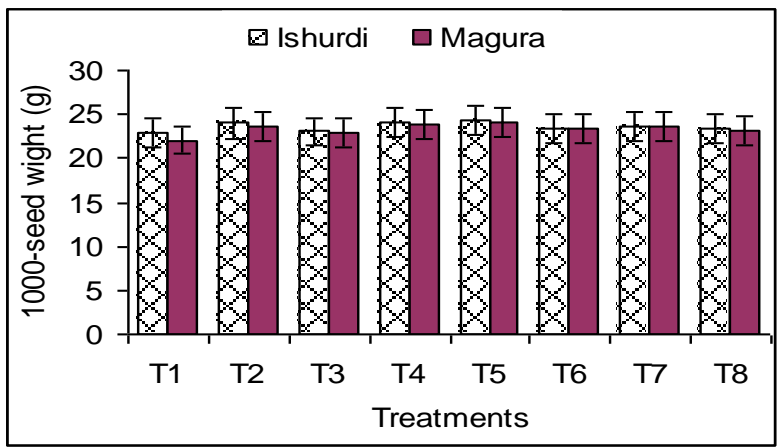

Fig.6. Effects of phosphatic biofertilizer with inorganic and organic sources of $\mathrm{P}$ on 1000-seed weight of lentil

Note: $\mathrm{T}_{1}$ : Control (No P), $\mathrm{T}_{2}: 100 \% \mathrm{P}$ from TSP, $\mathrm{T}_{3}: 50 \% \mathrm{P}$ from TSP, $\mathrm{T}_{4}: 100 \% \mathrm{P}$ from TSP+Phosphatic biofertilizer (PB), $\mathrm{T}_{5}: 50 \% \mathrm{P}$ from TSP $+\mathrm{PB}, \mathrm{T}_{6}: 50 \% \mathrm{P}$ from cowdung, $\mathrm{T}_{7}: 50 \% \mathrm{P}$ from cowdung $+\mathrm{PB}$ and $\mathrm{T}_{8}: \mathrm{PB}$. (Vertical bars indicate standard errors.) 


\section{Effects on seed and stover yields}

The Table 3 shows that the treatment $\mathrm{T}_{5}(50 \% \mathrm{P}$ from $\mathrm{TSP}+\mathrm{PB}$ ) gave significantly maximum seed yield of lentil (1.62 and $\left.1.36 \mathrm{t} \mathrm{ha}^{-1}\right)$ followed by the treatments $\mathrm{T}_{2}\left(1.51\right.$ and $\left.1.21 \mathrm{t} \mathrm{ha}^{-1}\right)$ at Ishurdi and Magura, respectively. But the treatments $\mathrm{T}_{2}(100 \% \mathrm{P}$ from TSP) and $\mathrm{T}_{5}(50 \% \mathrm{P}$ from $\mathrm{TSP}+\mathrm{PB})$ gave identical seed yields at both the locations. The treatment $\mathrm{T}_{4}(100 \% \mathrm{P}$ from $\mathrm{TSP}+\mathrm{PB})$ gave similar seed yields with the treatment $\mathrm{T}_{2}(100 \% \mathrm{P}$ from TSP) but it differed significantly with the treatment $\mathrm{T}_{5}$ (50\% $\mathrm{P}$ from TSP+PB) at Ishurdi. At Magura the treatment $\mathrm{T}_{5}$ showed statistically similar seed yields of lentil with the treatments $T_{2}, T_{3}$ and $T_{4}$. The treatment $\mathrm{T}_{6}(50 \% \mathrm{P}$ from $\mathrm{CD})$ gave insignificantly lower seed yield than the treatment $\mathrm{T}_{3}(50 \% \mathrm{P}$ from TSP) but they gave identical results with the treatments $\mathrm{T}_{7}(50 \% \mathrm{P}$ from $\mathrm{CD}+\mathrm{PB})$ and $\mathrm{T}_{8}(\mathrm{~PB})$ at both the locations (Table 3). However, phosphatic biofertilizer with 50\% P from CD gave higher seed yield of lentil to a some extent than 50\% P from CD alone at both the locations which indicated that phosphate solubilizing bacteria might be stimulated with the application of $\mathrm{CD}$. The treatment $\mathrm{T}_{1}$
(Control) gave significantly the lowest seed yield of lentil. Stover yields of lentil (Table 3) also significantly influenced with the different treatments at both the locations. The treatment $\mathrm{T}_{6}(50 \% \mathrm{P}$ from $\mathrm{CD})$ gave significantly maximum stover yield (3.57 and $3.22 \mathrm{t} \mathrm{ha}^{-1}$ at Ishurdi and Magura, respectively) of lentil followed by the treatment $\mathrm{T}_{5}(50 \% \mathrm{P}$ from $\mathrm{TSP}+\mathrm{PB})$. The lowest stover yield (2.39 and $2.45 \mathrm{tha}^{-}$ ${ }^{1}$ at Ishurdi and Magura, respectively) was recorded with the treatment $\mathrm{T}_{1}$ (Control). The results indicated that phosphatic biofertilizer with reduced rate of $\mathrm{P}$ i.e. 50\% P from TSP + Phosphatic biofertilizer (PB) gave comparable seed yields of lentil to the $100 \% \mathrm{P}$ from TSP alone. Jilani et al., (2007) reported that the PSB and plant growth promoting rhizobacteria (PGPR) together could reduce $\mathrm{P}$ fertilizer application by $50 \%$ without any significant reduction of crop yield. It infers that PSB inoculants / biofertilizers hold great prospects for sustaining crop production with optimized P fertilization. Kumar and Chandra (2008) also observed that inoculation of lentil seeds by PSB increased significantly grain $(23.5 \%)$ and straw yield $(14.0 \%)$ of lentil. The present study is well accordance with those earlier findings.

Table 3. Effects of phosphatic biofertilizer with inorganic and organic sources of $P$ on seed and stover yields of lentil

\begin{tabular}{|l|c|c|c|c|}
\hline \multirow{2}{*}{ Treatments } & \multicolumn{2}{c|}{ Ishurdi } & \multicolumn{2}{c|}{ Magura } \\
\cline { 2 - 5 } & $\begin{array}{c}\text { Seed yield } \\
\left(\mathrm{t} \mathrm{ha}^{-1}\right)\end{array}$ & $\begin{array}{c}\text { Stover yield } \\
\left(\mathrm{t} \mathrm{ha}^{-1}\right)\end{array}$ & $\begin{array}{c}\text { Seed yield } \\
\left(\mathrm{t} \mathrm{ha}^{-1}\right)\end{array}$ & $\begin{array}{c}\text { Stover } \\
\text { yield } \\
\left(\mathrm{t} \mathrm{ha}^{-1}\right)\end{array}$ \\
\hline $\mathrm{T}_{1}:$ Control & $0.95 \mathrm{~d}$ & $2.39 \mathrm{~d}$ & $0.86 \mathrm{c}$ & $2.45 \mathrm{~b}$ \\
$\mathrm{~T}_{2}: 100 \%$ P from TSP & $1.51 \mathrm{ab}$ & $3.21 \mathrm{ab}$ & $1.21 \mathrm{ab}$ & $3.02 \mathrm{a}$ \\
$\mathrm{T}_{3}: 50 \%$ P from TSP & $1.28 \mathrm{bc}$ & $2.93 \mathrm{bc}$ & $1.12 \mathrm{~b}$ & $2.81 \mathrm{ab}$ \\
$\mathrm{T}_{4}: 100 \%$ P from TSP+Phosphatic biofertilizer (PB) & $1.36 \mathrm{bc}$ & $2.88 \mathrm{bc}$ & $1.16 \mathrm{ab}$ & $3.12 \mathrm{a}$ \\
$\mathrm{T}_{5}: 50 \%$ P fromTSP +PB & $1.62 \mathrm{a}$ & $3.07 \mathrm{bc}$ & $1.36 \mathrm{a}$ & $3.18 \mathrm{a}$ \\
$\mathrm{T}_{6}: 50 \%$ P from cowdung & $1.23 \mathrm{c}$ & $3.57 \mathrm{a}$ & $1.06 \mathrm{bc}$ & $3.22 \mathrm{a}$ \\
$\mathrm{T}_{7}: 50 \% \mathrm{P}$ from cowdung+PB & $1.26 \mathrm{c}$ & $.81 \mathrm{bcd}$ & $1.08 \mathrm{~b}$ & $2.83 \mathrm{ab}$ \\
$\mathrm{T}_{8}: \mathrm{PB}$ & $1.21 \mathrm{c}$ & $2.64 \mathrm{~cd}$ & $1.10 \mathrm{~b}$ & $2.95 \mathrm{ab}$ \\
\hline $\mathrm{CV}(\%)$ & 9.81 & 8.30 & 10.95 & 9.34 \\
\hline
\end{tabular}

In a column figures having common letter(s) do not differ significantly at 5\% level of significance as per DMRT

\section{Effects on total P uptake}

Inoculation of lentil seeds by phosphatic biofertilizer (PB) also significantly influenced the total $\mathrm{P}$ uptake by lentil at Ishurdi and Magura (Table 4). The treatment $\mathrm{T}_{5} \quad(50 \% \quad \mathrm{P}$ from $\mathrm{TSP}+\mathrm{PB})$ showed maximum total $\mathrm{P}$ uptake (12.29 and $10.72 \mathrm{~kg} \mathrm{P} \mathrm{ha}^{-1}$ at Ishurdi and Mgura, respectively) with the highest $\mathrm{P}$ uptake increased over control (37.9\% at Ishurdi and $35.2 \%$ at Magura) followed by the treatments $\mathrm{T}_{4}$ and
$\mathrm{T}_{2}$ (Table 4). Similar findings were also obtained by Kumar and Chandra (2008). The treatment $\mathrm{T}_{1}$ (control) gave the lowest $\mathrm{P}$ uptake at both the locations. The results revealed that application of $\mathrm{PB}$ with inorganic or organic sources of $\mathrm{P}$ fertilizer increased $\mathrm{P}$ uptake and $\mathrm{P}$ use efficiency by lentil crop. Khatik et al. (2004) reported that combined use of rock phosphate (RP), farm yard manure (FYM) and biofertilizer helped in better utilization of both 
fertilizer $\mathrm{P}$ and soil $\mathrm{P}$. Application of phosphatic biofertilizer increased $\mathrm{P}$ uptake by the different crops are also reported by many workers (Kundu et al.,
2006; Linu et al., 2009). The present findings are well supported with those findings.

Table 4. Effects of phosphatic biofertilizer with inorganic and organic sources of $\mathrm{P}$ on $\mathrm{P}$ uptake by lentil

\begin{tabular}{|l|c|c|c|c|}
\hline \multirow{2}{*}{ Treatments } & \multicolumn{2}{|c|}{ Ishurdi } & \multicolumn{2}{c|}{ Magura } \\
\cline { 2 - 5 } & Total P uptake $\left(\mathrm{kg} \mathrm{ha}^{-1}\right)$ & $\begin{array}{c}\text { P uptake } \\
\text { increased over } \\
\text { control }(\%)\end{array}$ & $\begin{array}{l}\text { Total P } \\
\text { uptake }(\mathrm{kg} \\
\left.\text { ha }^{-1}\right)\end{array}$ & $\begin{array}{c}\text { P uptake } \\
\text { increased over } \\
\text { control (\%) }\end{array}$ \\
\hline $\mathrm{T}_{1}:$ Control & $8.91 \mathrm{c}$ & - & $7.93 \mathrm{c}$ & - \\
$\mathrm{T}_{2}: 100 \%$ P from TSP & $11.51 \mathrm{ab}$ & 29.2 & $9.87 \mathrm{ab}$ & 24.4 \\
$\mathrm{~T}_{3}: 50 \%$ P from TSP & $10.56 \mathrm{~b}$ & 18.5 & $9.42 \mathrm{~b}$ & 18.8 \\
$\mathrm{~T}_{4}: 100 \%$ P from TSP+Phosphatic & $11.92 \mathrm{a}$ & 33.8 & $10.27 \mathrm{a}$ & 29.5 \\
biofertilizer (PB) & & & & \\
$\mathrm{T}_{5}: 50 \%$ P fromTSP + PB & $12.29 \mathrm{a}$ & 37.9 & $10.72 \mathrm{a}$ & 35.2 \\
$\mathrm{~T}_{6}: 50 \%$ P from cowdung & $10.51 \mathrm{~b}$ & 17.9 & $9.30 \mathrm{~b}$ & 17.3 \\
$\mathrm{~T}_{7}: 50 \%$ P from cowdung +PB & $10.82 \mathrm{~b}$ & 21.5 & $9.43 \mathrm{~b}$ & 19.0 \\
$\mathrm{~T}_{8}:$ PB & $10.38 \mathrm{~b}$ & 16.5 & $9.42 \mathrm{~b}$ & 18.7 \\
\hline $\mathrm{CV}(\%)$ & 6.8 & \multicolumn{5}{|}{} \\
\hline
\end{tabular}

\section{Conclusion}

From the results it can be concluded that $50 \%$ inorganic or organic sources of $\mathrm{P}$ fertilizers can be saved with the integrated use of phosphatic biofertilizer for the cultivation of lentil at different locations of Bangladesh.

\section{References}

Alam, S. S.; Khalil, S.; Ayub, N. and Rashid, M. 2002. In vitro solubilization of inorganic phosphate by phosphate solubilizing microorganism (PSM) from maize rhizosphere. Intl. J. Agric. Biol., 4:454458.

Chang, C. H. and Yang, S. S. 2009. Thermo-tolerant phosphate-solubilizing microbes for multifunctional biofertilizer preparation. Bioresour. Technol., 100: 1648-1658.

Donahue, R. L.; Milller, R. W. and Shickluna, J. C. 1990. An Introduction to Soils and Plant Growth. Prentice Hall of India Private Ltd., New Delhi, pp: 222.

Fankem, H.; Nwaga, D.; Deubel, A.; Dieng, L.; Merbach, W. and Etoa, F. X. 2006. Occurrrence and functioning of phosphate solubilizing microorganisms from oil palm tree (Elaeis guineensis) rhizosphere in
Cameroon. African J. Biotech., 5:24502460.

Gull, M.; F. Y.; Saleem, M. and Malik, K. A. 2004. Phosphorus uptake and growth promotion of chickpea by co-inoculation of mineral phosphate solubilizing bacteria and a mixed rhizobial culture. Aust. J. Exptl. Agric., 44(6): 623 - 628 .

Jilani, G.; Akram, A.; Ali, R. M.; Hafeez, F. Y., Shamsi, I. H.; Chaudhry, A. N. and Chaudhry, A. G. 2007. Enhancing crop growth, nutrients availability, economics and beneficial rhizosphere microflora through organic and biofertilizers. Ann. Microbiol., 57:177-183.

Khatik, S. K.; Deshmukh, K. K.; Sharma, G. D. and Dwivedi, B. S. 2004. Effect of FYM, rock phosphate and biofertilizer on utilization of phosphorus by gram (Cicer arietinum) and its transformation in soil. J. Nuclear Agric. Biol., 33 (1): 39-48.

Khiari, L. and Parent, L. E. 2005. Phosphorus transformations in acid soil light-textured soils treated with dry swine manure. Can. J. Soil Sci. Soc., 85:75-87.

Kumar, R. and Chandra, R. 2008. Influence of PGPR and PSB on Rhizobium leguminosarum Bv. viciae Strain Competition and 
Symbiotic Performance in Lentil. World $J$. Agril. Sci., 4 (3): 297-301.

Kumari, M.; Vasu, D.; Ul-Hasan, Z. and Dhurwe, U. K. 2009. Effects of PSB (Phosphate Solubilizing Bacteria) morphological on characters of Lens culinaris Medic. Biological Forum - An International Journal, 1(2): 5-7.

Kundu, B. S.; Nandal, S.; Tiwari, M. and Tomar, M. 2006. Establishment and influence of phosphate solubilizing bacteria on pearl millet. Indian J. Pl. Physiol., 11(2): 201205.

Linu, M. S.; Stephen J. and Jisha. M. S. 2009. Phosphate solubilizing Gluconacetobacter sp., Burkholderia sp. and their potential interaction with cowpea (Vigna unguiculata (L.) Walp.). Int. J. Agric. Res., 4: 79-87.

Rudresh, D. L.; Shivaprakash M. K. and Prasad, R. D. 2005. Tricalcium phosphate solubilizing abilities of Trichoderma spp. in relation to $\mathrm{P}$ uptake and growth and yield parameters of chickpea (Cicer arietinum L.). Can. J. Microbiol., 51: 217222.

Singh,Y. P.; Chauhan, C. P. S. and Gupta, R. K. 2000. Effect of sulphur, phosphorus and inoculation on reasonable seed size, growth, yield and sulphur utilization by lentil (Lens culinaris). Indian J. Agric. Sci., 70: 491-493.

Singh, O. N.; Sharma, M. and Dash, R. 2003. Effect of seed rate, phosphorus and FYM application on growth and yield of bold seeded lentil. Pulses Res., 16: 116-118.

Vassileva, M.; Vassileva, N.; Fenice, M. and Federici, F. 2001. Immobilized cell technology applied in solubilization of insoluble inorganic (rock) phosphate and $\mathrm{P}$ plant acquisition. Biores. Technol., 79: 263-271.

Vikram, A. 2007. Efficacy of phosphate solubilizing bacteria isolated from vertisols on growth and yield parameters of sorghum. Res. J. Microbiol., 2: 550-559.

Yadav, J.; Yadav, S. and Singh, S. G. 2011. Plant growth promotion in wheat crop under environmental condition by PSB as biofertilizer. Res. J. Agril. Sci., 2(1): 76-78.

Yoshida, R. K. 1976. Studies on organic phosphorus compounds in soil, isolation of inositol. Soil Sci., 60: 81-89. 